institutional analysis as well as ethnographic narratives of rural migrant workers, a sectoral analysis of the construction industry, and a case study of factories operated by the giant Foxconn corporation. The book will be an invaluable read for students and general readers with an interest in labor issues in China and the dynamics of global capitalism.

\title{
Chunyun Li
}

London School of Economics

China at Work: A Labour Process Perspective on the Transformation of Work and Employment in China, edited by Mingwei Liu and Chris Smith. London: Palgrave Macmillan, 2016. v+399 pp. $£ 75.00$ (cloth), $£ 48.99$ (paper).

In the past few years, much has been written about the rising activism of China's workers, with the media as well as the academy propagating the idea that a "rights awakening" is allegedly taking place among China's large population of migrant laborers. Still, this shift in the narrative of Chinese labor may have been premature. In an essay published 2016 in the Journal of Asian Studies, labor sociologist Ching Kwan Lee chided her fellow labor scholars for producing an "exaggerated assessment of worker power" (329) in China. Lee invited the academic community to remember Gramsci's famous motto, "pessimism of the intellect and optimism of the will” (330).

China at Work, a volume of essays coedited by Mingwei Liu and Chris Smith, heeds this call and helps to bring China's labor studies on to more solid-and less idealistic-ground. It does so by adopting a series of perspectives rooted in the empirical realities of the labor process. As the editors note in their introduction, "Chinese workers, employers, and local governments are much more diversified and the interactions and relationships among the three actors are much more complicated than the existing scholarship has revealed" (3). For this reason, they advocate a workplace-based approach, which enables us "to see in microcosm the acting out of systemic and local practices, and judge how agential action penetrates structures in dynamic and emerging ways" (6).

The first of the book's four sections deals with work and employment by sector and firm. It offers several remarkable studies in settings that range from traditional state-owned enterprises in the steel, shipbuilding, and heavy machinery sectors, to privately owned garment factories, call centers, and subsidiaries of Japanese and Korean transnational companies. The second of the book's sections delves into issues related to trade unions and collective bargaining in China, with three contributions that examine the responses of employers to labor shortages, collec- 
tive consultations in the auto industry, and the implications of the recent direct elections of workplace union leaders. The third section looks into strikes and labor activism in China. It contains a case study of worker mobilization in a Walmart store led by a workplace union in collaboration with labor NGOs and another study on the involvement of workers in collective bargaining in the auto industry. The fourth section forays into the underresearched realm of industrial relations in Chinese companies abroad. This includes a notable study of the strategies of labor control implemented in Foxconn plants in the Czech Republic and in Turkey, and a critical review of the existing literature on outward foreign direct investment.

The essays included in the volume are far too diverse to be presented here in detail. However, they all share a common feature-their rootedness in the daily reality of working life in Chinese factories. Most of the authors are young scholars who have carried out considerable fieldwork and have been embedded in different workplaces in China. These experiences have allowed them to gain notable insights into the grassroots dynamics of labor relations in Chinese workplaces. While deeply empirically grounded, most of the chapters do not refrain from engaging critically with the existing theoretical literature. In particular, the influence of one scholar stands out among all others: that of Michael Burawoy. His theorizations on labor regimes have contributed more than anything else to shape the field of Chinese labor studies in the past couple of decades. As this volume highlights, the debate on despotism and hegemony in Chinese labor relations is ongoing and not likely to dry up anytime soon.

On the down side, not all of the chapters are up to standard-some read more like field notes than proper essays - and the book also would have benefited from a more careful proofreading. These flaws notwithstanding, China at Work is fundamental reading for students, scholars, activists, and policy makers interested in understanding the complexity of labor issues in contemporary China, without any ideological oversimplification or comforting wishful thinking.

Ivan Franceschini

Australian National University

Understanding China's Urbanization: The Great Demographic, Spatial, Economic, and Social Transformation, by Li Zhang, Richard LeGates, and Min Zhao. Cheltenham: Edward Elgar Publishing, 2016. v+426 pp. $£ 100.00$ (cloth).

As a collaboration between two Chinese academics and a US academic that is based on field observations, interviews, surveys, and data analysis, Understanding China's Urbanization offers a comprehensive account of the processes, influencing factors, 